\title{
Udvartana ( Massage Therapy)
}

\author{
DR. RITU WADHWA ${ }^{1 *}$, M.D. Kayachikitsa ${ }^{2}$ \\ professor. Panchkarma, D.Y.Patil School Of Ayurveda, Nerul, Navi Mumbai
}

*Corresponding Author: DR. RITU WADHWA, professor. Panchkarma, D.Y.Patil School Of Ayurveda, Nerul, Navi Mumbai

\section{INTRODUCTION}

The procedure of massaging the whole body below the neck in a direction opposite to the orientation of hair with some pressure is called Udvartana. Udvartana is a special type of Abhyanga (massage) in which Herbal powders are used for massaging ( sometimes oil may be added in herbal powder). Acharya Charaka has mentioned a term called Sharira Parimarjanal. Commentator Chakrapani commenting on the term tells that Sharira Parimarjana is nothing different from Udvartan. In fact Sharira parimarjana explained by Charaka is Udvartana. Chakrapani states that Udvartana has to be done after Abhyanga (massage) and since Charaka explains Sharira Parimarjana after Abhyanga, it should be an explanation of Udvartana.Thus ShariraParimarjana can be considered as synonym of Udvartana.

Types of Udvartana - According to Acharya Charak

Snigdha (oily) and rooksha (dry)

\section{Snigdha Udvartana:}

Snigdha means with Sneha (fats like medicated oil, medicated ghee etc). In this type of Udvartana, the herbal powders are not directly rubbed over the body. In fact, the powders are mixed with medicated oils or ghee and made into paste. This paste is rubbed over the body in reverse direction (from below upwards) after doing Abhyanga (massage).

Moreover powder of drugs which naturally has unctuous (oily) property like sesame etc is used in this type of treatment.

Indications for Snigdha Udvaratna -

- When the patient is lean \& thin,weak, then we intend udvartana to provide strength

- When there is instability or laxity of body parts and when we are intending to provide stability (sthairyakaram)

- Where the skin is depleted of nutrition, looking lack lustre (dry skin) and devoid of complexion or glow, to improve skin immunity and health.

- When the patient is of Vata Prakriti (constitution) or having Vata Vikriti (diseases caused by morbid Vata)

\# Choice of oil according to prakriti

\begin{tabular}{|l|l|}
\hline Vata Prakriti & Himsagara Taila(oil) \\
\hline Pitta Prakriti & Chandanadi Taila, Chandanabalalakshadi Taila \\
\hline Kapha Prakriti & Triphaladya Taila \\
\hline Sama Prakriti & Asanabilvadi Taila. \\
\hline
\end{tabular}

Ruksha

Udvartana:

Ruksha means Dry. The name itself indicates that no oil is used in this procedure. This is opposite of Snigdha Udvartana. This means herbal powders are directly rubbed or stroked (without mixing or frying them with oil or ghee) over the body in upward direction after conducting Abhyanga. 
Moreover powder of drugs which naturally has dry (ruksha) property like lodhra, trifala etc are used in this type of treatment.

Rooksha Udvartana may lead to small complications like small skin abrasions or skin damage especially when done in people with sensitive skin or dry skin.

Indications - Ruksha Udvartana is recommended in following conditions -

- Where there is severe morbidity of Kapha

- When the patient is strong enough to tolerate dry and depleting form of treatment

- When there is excess fat (obesity) / cholesterol in the body (ruksha udwartana being the best treatment in relieving body fat and subcutaneous fat).

- Where there is heaviness,stiffness, cold and rigidity in the body

- When there is severe lethargy, laziness and drowsiness, lack of freshness.

\#Choice of herbs as per indications.

\begin{tabular}{|l|l|}
\hline Kulatta Churna (powder) & $\begin{array}{l}\text { To reduce accumulated subcutaneous fat and to } \\
\text { decrease excessive sweating. }\end{array}$ \\
\hline Kolkulattadi Churna & In obese patients, neurological conditions \\
\hline Triphala Churna & In obese patients, skin diseases \\
\hline Nalpamaradi Churna & $\begin{array}{l}\text { Eczema, fungal infections, diabetes mellitus associated } \\
\text { with itching. }\end{array}$ \\
\hline Nimba Churna & Skin Diseases \\
\hline Ushira, Chandana, Musta, Padam Churna & Excessive sweating \\
\hline $\begin{array}{l}\text { Nimba, Khadira, Guduchi, Aragvadha, Karanja } \\
\text { Churna }\end{array}$ & Skin Diseases \\
\hline Shailayadi Churna & Obesity \\
\hline
\end{tabular}

Types according to Sushruta: According to Sushruta, Udvartana again is of 3 types $^{2}-$ 1.Udvartana

Udvartana is that which brings about Pravilapanam(dissolution or liquification) and Vimplapanam(mutilation - destroying anything). ${ }^{3}$ Thus in this, herbal powders are rubbed on the body in an upward (reverse) direction so as to cause dissolution or mutilation of the unwanted and undesired elements of the body, mainly fat and excess kapha which are causing blocks and also helps to mobilize them out of the body to establish normalcy and health. This can be achieved when dry things are rubbed over the body (drugs or powders which are naturally dry or can cause dryness on rubbing).

To mobilize or mutilate fat or any blocking elements, rubbing should be done with sufficient pressure so that the effect reaches into the deep tissues.

\section{UDGHARSHANA}

अस्नेह औषध चूर्णादिभिः घर्षणम् उद्धर्षणम्। \{डल्हण, सु.चि.२४/५२\}

Rubbing the powders of medicinal drugs over the body without the addition or admixture of oil or ghee is called Udgharshanam.

\# For Siramukha Vivitaktavum

\begin{tabular}{|l|l|}
\hline Mrittika Churna & To reduce oiliness in the skin \\
\hline Brick Powder & For Udgharshana, Kandu, Kotha \\
\hline Wood Powder & For Udgarshana \\
\hline Reetha Powder & For Udgarshana \\
\hline
\end{tabular}

\section{UTSADANA}

सस्नेह कल्केन उद्धर्षणम् उत्सादनम्। \{डल्हण, सु.चि. २४/५२\}

In utsadana, the powders of medicinal drugs are mixed with sneha (oils or ghee) so as to make a paste. This paste is rubbed over the body in a reverse (upward direction over the body). 
Procedure $^{4}$

Application of medicated oil as indicated and dusting of herbal powder on the body followed by massage with some pressure in the direction opposite to that of hair is the main method adopted in Udvartana. Various steps involved in this procedure are:-

\section{Preparation of the Patient:}

Ideal time for Udvartana is the morning hour after evacuating the bowel and bladder. It should be performed empty stomach and before bath. Mild exercise may be advised to the patient before the procedure. Therapist should start the procedure after chanting prayer.

\section{Main Procedure}

\section{Position of the patient}

Patient wearing minimum copin is advised to lie down on the Abhyanga table. There are four positions in which Udvartana is carried out. These include supine position, left lateral, prone and right lateral positions.

At first patient is advised to lie down in supine position and udvartana is done on the anterior part of the body. Second position is the left lateral position and Udvartana is done on the right lateral aspect of the body. Third position is the prone position in which, posterior part of the body is treated with Udvartana. At last, patient is advised to take right lateral position and udvartana is carried out in left lateral aspect of body. Udvartana is done on each part of the body below the neck by exerting some pressure.

\section{Types of Massage on different parts of the body}

\begin{tabular}{|l|l|l|}
\hline Parts of Body & Position of Patient & Type of Massage \\
\hline Arms & Supine, Lateral and prone position & Linear Massage \\
\hline $\begin{array}{l}\text { Hands (both palmer and dorsal } \\
\text { aspect) }\end{array}$ & Supine and prone position & Circular Massage \\
\hline Shoulders & Supine, Lateral and prone position & $\begin{array}{l}\text { Circular Massage (both in } \\
\text { clockwise and anticlockwise } \\
\text { direction) }\end{array}$ \\
\hline Abdomen & Supine position & $\begin{array}{l}\text { Linear and Circular Massage(both } \\
\text { in clockwise and anticlockwise } \\
\text { direction) }\end{array}$ \\
\hline Chest & Supine position & $\begin{array}{l}\text { Linear and Circular Massage(both } \\
\text { in clockwise and anticlockwise } \\
\text { direction) }\end{array}$ \\
\hline Back & Prone position & Linear Massage \\
\hline Legs & Supine, Lateral and prone position & Linear Massage \\
\hline Soles & Supine and prone position & $\begin{array}{l}\text { Rubbing Massage( to and fro } \\
\text { manner) }\end{array}$ \\
\hline Trunk & Supine, Lateral and prone position & Linear Massage \\
\hline
\end{tabular}

\section{Duration of Udvartana}

Each part of the body in their respective positions is massaged for 3-5 minutes. Usually the duration of Udvartana is 30-45 minutes. The number of days of treatment varies from 7-14 days depending on the nature and intensity of the disease.

\section{Post Procedural Activities}

- Patient is advised to take rest for at least 15 minutes.

- Patient is allowed to take bath with lukewarm water after an interval of minimum 1 hour.

\section{Care \&Precautions}

- Before Udvartana, bladder and bowel should be emptied.

- It is to be done in the direction opposite to that of the hair. 
- Type of massage on different parts of the body and position of the patient during the procedure should be followed strictly.

- Indications and choice of drug to be used should be assessed before Udvartana.

- Tender areas should be avoided for Udvartana.

- Precaution should be taken while dusting the powder over the body. It is advisable to protect face, nose and eyes to prevent irritation.

- Aseptic measures should be taken if patient is suffering from any contagious disease.

\section{DISCUSSION}

Utsaadana is administered in an unctuous form as the powder is made into a paste by addition of lipids. It is also mentioned that Utsaadana provides glow, beauty and complexion, especially when it is administered in women. Thus Utsadana looks like a retrograde massage which is administered for skin beautification.

Udgharshana and Utsadana brings about dilatation of channels and orifices of the body, removing the blocks and thus enabling free transportation of nutrients and essentials. This motive is possible achieved by both these methods. I think that it is better achieved when these two are done in combination. Udgharshana serves the purpose of exfoliation and removes dead cells and debris, dirt and dust from the cells of the skin and tissues below the skin. It also mobilizes the fat collection. Later when Utsadana is done,, it improves the glow and complexion of the skin and restores immunity and health of the skin.

Udvartana - nothing has been mentioned about the addition or exclusion of Sneha (oil/ghee). But seeing the utility of Udvartana (Pravilapana and Vimplapana) we can infer that it is also a predominantly dry procedure. But immediately after Udvartana, Udgharshana has been explained excluding the oil from the procedure. This gives us an idea that Udvartana could be partly dry (Ruksha) and partly unctuous (Snigdha).

\section{CONCLUSION}

Udvartana is a multi-dimensional treatment. It removes blocks, rectifies metabolism, soothes nerves, de-stresses our body and mind, enhances blood circulation, enriches the cells with proper nutrients and essentials, detoxifies the system, provides energy, revitalizes and rejuvenates us and enhances the lifespan of cells. It makes our body toned and trimmed up and alleviates many diseases.

\section{REFERENCES}

1. Sharira Parimarjanam -अभ्यड्गपूर्वकत्वाद् उद्र्तनस्य तमनुपरिमार्जनमुद्रत्तनं ब्रूतो। चक्रपाणि च.सू.५/९३,९४, Ref - Chakrapani commentary on Charaka Sutra Sthana Ch.5, verses 93,94\}

2. उद्वर्तनं चात्र प्रविलापनीय विम्लापन करम्। उद्धर्षणम् स्नेह औशध चूर्णादिभिः घर्षणम्॥ स्नेहस्य कल्केन उद्धर्षणं उत्सादनम्। डडल्हण सु.चि.२४/५६ $\}$ Ref - Dalhana commentary on Sushruta Chikitsa Sthana Ch.24, verses 56 सिरामुख विविक्तत्वं त्वक्स्थ अस्य अग्ने: च तेजसं। उद्धर्षण उत्सादनाभ्यां जाययेताम् असंशयम्॥ उत्सादनात् भवेत् स्रीणां विशेषात् कांतिमत् वपुः॥ सु.चि. २४/५२,५३\} 3. उद्वर्तनं च अत्र प्रविलापनीय विम्लापनकरम्। \{डल्हण, सु.चि.२४/५१\} ef - Sushruta Chikitsa Sthana Ch.24, verses 52, 53

4. Text Book of Panchakarma by Dr. Ashish Mhatre \& Dr. Paresh Kateria chepter 2 pg. No. 67.

Citation: DR. RITU WADHWA \& M.D. Kayachikitsa (2020). "Udvartana ( Massage Therapy)". International Journal of Medicinal Plants and Natural Products (IJMPNP), 6(3), pp.24-27. http://dx.doi.org/ 10.20431/2454-7999.0603003

Copyright: (C) 2020 Authors. This is an open-access article distributed under the terms of the Creative Commons Attribution License, which permits unrestricted use, distribution, and reproduction in any medium, provided the original author and source are credited. 